\title{
KESADARAN MAHASISWA FAKULTAS ILMU KEOLAHRAGAAN UNIVERSITAS NEGERI YOGYAKARTA TERHADAP KESEHATAN LINGKUNGAN KAMPUS
}

\author{
Oleh: Erwin Setyo Kriswanto \\ Dosen Jurusan Pendidikan Olahraga, FIK UNY
}

\begin{abstract}
Abstrak
Penelitian ini bertujuan untuk mengetahui kesadaran Mahasiswa Fakultas Ilmu Keolahragaan Universitas Negeri Yogyakarta Terhadap Kesehatan Lingkungan Kampus. Terciptanya mahasiswa yang sehat, mandiri dan berkemampuan akan menjadi kebanggaan tersendiri saat mereka berhasil mengaplikasikan kesehatan lingkungan dengan baik.

Penelitian ini merupakan penelitian deskriptif yang akan mendeskripsikan atau menggambarkan suatu keadaan khususnya tentang tingkat kesadaran mahasiswa Fakultas ilmu Keolahragaan Universitas Negeri Yogyakarta terhadap Kesehatan Lingkungan Kampus. Metode yang digunakan adalah survei dengan menggunakan instrumen angket. Populasi penelitian ini adalah mahasiswa Fakultas Ilmu Keolahragaan Universitas Negeri Yogyakarta. Teknik penentuan sampel menggunakan random sampling sejumlah 462. Analisis data yang digunakan dalam penelitian ini menggunakan teknik analisis data deskriptif kuantitatif yang dituangkan dalam bentuk persentase.

Berdasarkan hasil penelitian dapat disimpulkan bahwa kesadaran mahasiswa Fakultas Ilmu keolahragaan terhadap kesehatan lingkungan kampus adalah sebanyak 129 mahasiswa $(27,92 \%)$ dengan kategori sangat baik, 309 mahasiswa $(66,88 \%)$ dengan kategori baik, dan 24 mahasiswa (5,20 \%) dengan kategori sedang, 0 mahasiswa $(0,00 \%)$ dengan kategori kurang, dan 0 mahasiswa $(0,00 \%)$ dengan kategori sangat kurang.
\end{abstract}

Kata Kunci: kesadaran mahasiswa, kesehatan lingkungan

Kesehatan lingkungan merupakan faktor penting dalam kehidupan sosial kemasyarakatan, bahkan merupakan salah satu unsur penentu atau determinan dalam kesejahteraan penduduk. Lingkungan yang sehat sangat dibutuhkan bukan hanya untuk meningkatkan derajat kesehatan masyarakat, tetapi juga untuk kenyamanan hidup dan meningkatkan efisiensi kerja dan belajar. Berdasarkan Undang-Undang No. 39 Tahun 2009 pasal 79

Kesadaran Mahasiswa Fakultas Ilmu Keolahragaan Universitas Negeri Yogyakarta terhadap Kesehatan Lingkungan Kampus (Erwin Setyo Kriswanto) 
tentang kesehatan disebutkan bahwa kesehatan diselenggarakan untuk meningkatkan kemampuan hidup sehat peserta didik (anak sekolah) dalam lingkungan hidup sehat sehingga peserta didik dapat belajar, tumbuh dan berkembang secara harmonis dan optimal untuk menjadi sumber daya manusia yang lebih berkualitas (Depkes RI 2009:31).

Kehidupan manusia sendiri tidak bisa dipisahkan dari baik lingkungan alam maupun lingkungan sosial. Sebagai individu, mahasiswa seharusnya dapat menjaga kesehatan lingkungannya. Semua itu tidak dapat dijalankan tanpa adanya kesadaran dari setiap individu masyarakat maupun kelompok masyarakat. Perguruan tinggi merupakan salah satu lembaga formal pendidikan yang berfungsi untuk meningkatkan pengetahuan dan kemampuan mahasiswa, perguruan tinggi merupakan tempat memperoleh berbagai ilmu pengetahuan sebagai bekal untuk bertahan hidup di kemudian hari. Keadaan kesehatan lingkungan perguruan tinggi yang baik sangat dibutuhkan sebagai daya dukung kenyamanan dalam belajar. Untuk meningkatkan kesehatan lingkungan diperlukan kesadaran oleh sivitas akademika di antaranya adalah mahasiswa. Masalah utama adalah pada perilaku mahasiswa khususnya di Fakultas Ilmu Keolahragaan masih adanya mahasiswa yang tidak mau mengikuti aturan-aturan yang diberikan oleh lembaga atau fakultas terkait dengan kesehatan lingkungan. Masih ada mahasiswa yang tidak mau repot hanya untuk membuang sampah pada tempatnya, kebiasaan untuk menggelontor sesudah buang air juga masih kurang, keadaan tersebut bisa dilihat pada kamar mandi atau toilet yang bau aromanya kurang sedap termasuk dalam memarkir kendaraannya.

Fenomena lain yang masih bisa dijumpai terhadap kesadaran mahasiswa mengenai kesehatan lingkungan adalah masih adanya mahasiswa yang merokok di lingkungan kampus padahal sudah terpampang jelas tulisan "Kampus Bebas Asap Rokok". Aspek merokok dan pengelolaan sampah diikutsertakan karena di sudut-sudut kampus sekitar ruang kelas ataupun halaman selalu ada pemandangan abu rokok atau puntung rokok dan sampah-sampah yang tidak berada pada tempat semestinya.

Penelitian ini bertujuan untuk mengetahui kesadaran mahasiswa Fakultas Ilmu Keolahragaan Universitas Negeri Yogyakarta terhadap kesehatan lingkungan kampus. Terciptanya mahasiswa yang sehat, mandiri, dan berkemampuan akan menjadi harapan tersendiri saat mereka berhasil mengaplikasikan kesehatan lingkungan dengan baik. 
Kesadaran yang tinggi terhadap kesehatan lingkungan akan menciptakan kenyamanan dalam belajar. Tercipta kampus yang sehat, rapih, dan bersih merupakan dambaan bagi civitas akademika maupun masyarakat.

\section{HAKIKAT KESADARAN LINGKUNGAN}

Secara harafiah kata kesadaran berasal dari kata sadar, yang berarti insyaf, merasa tahu dan mengerti, jadi kesadaran adalah keadaan seseorang yang tahu/mengerti dengan jelas apa yang ada dalam pikirannya. Pikiran bisa diartikan dalam banyak makna, seperti ingatan, hasil berpikir, akal, gagasan ataupun maksud/niat. Hal tersebut seperti dikatakan AW Widjaja (1984: 46) yang menyatakan bahwa kita sadar jika orang tahu, mengerti, insyaf, dan yakin tentang kondisi tertentu. Dengan demikian kesadaran adalah keinsyafan atau merasa mengerti tentang segala sesuatu

Lingkungan adalah segala sesuatu yang ada di sekitar manusia yang memengaruhi perkembangan hidup manusia baik langsung maupun tidak langsung. Lingkungan terbagi atas dua yaitu, lingkungan abiotik dan biotik. UU no. 23 tahun 1997 menyebutkan bahwa kesatuan ruang dengan semua benda dan kesatuan makhluk hidup termasuk di dalamnya manusia dan perilaku manusia yang melangsungkan perikehidupan dan kesejahteraan manusia serta makhluk hidup lainnya.

Menurut Erwin Setyo Kriswanto (2012: 6) kesehatan lingkungan adalah keseimbangan ekologis terhadap berbagai masalah kesehatan sebagai akibat hubungan interaktif antara berbagai bahan, kekuatan, kehidupan, zat, yang memiliki potensi penyebab sakit yang timbul akibat adanya perubahan lingkungan masyarakat, serta menerapkan upaya pencegahan gangguan kesehatan yang ditimbulkannya. Kesehatan lingkungan dapat diartikan sebagai ilmu yang mempelajari interaksi antara lingkungan dan kesehatan manusia, tumbuhan, dan hewan dengan tujuan untuk meningkatkan faktor lingkungan yang menguntungkan (eugenik) dan mengendalikan faktor yang merugikan atau disgenik (Juli Soemirat, 2011: 13).

Kesadaran lingkungan merupakan keadaan individu masyarakat yang menyadari pentingnya sebuah ruang lingkup (lingkungan) yang di dalamnya, terdapat makhlukmakhluk hidup yang harus dijaga kelestariannya. Kesadaran untuk membuat kesimbangan 
ekologis terhadap berbagai masalah kesehatan sebagai akibat hubungan interaktif antara berbagai bahan, kekuatan, kehidupan, zat, yang memiliki potensi penyebab sakit yang timbul akibat adanya perubahan lingkungan masyarakat, serta menerapkan upaya pencegahan gangguan kesehatan yang ditimbulkannya.

\section{RUANG LINGKUP KESEHATAN LINGKUNGAN}

Ruang lingkup kesehatan lingkungan menurut Soekidjo Notoatmodjo (2003: 147) meliputi perumahan, pembuangan kotoran manusia (tinja), penyediaan air bersih, pembuangan sampah, pembuangan air kotor (limbah), rumah hewan ternak (kandang). Menurut Juli Soemirat (2011: 14) ruang lingkup kesehatan lingkungan meliputi: (1) penyediaan air minum, (2) pengolahan dan pembungan limbah cair, padat dan gas, 3) mencegah kebisingan, (4) mencegah kecelakaan, (5) mencegah penyakit bawaan, air, udara, makanan dan vector, dan (6) pengelolaan kualitas lingkungan air, udara, makanan, pemukiman, dan bahan berbahaya.

\section{METODE PENELITIAN}

Penelitian ini merupakan penelitian deskriptif yang akan mendeskripsikan atau menggambarkan suatu keadaan khususnya tentang tingkat kesadaran mahasiswa Fakultas Ilmu Keolahragaan Universitas Negeri Yogyakarta terhadap kesehatan lingkungan kampus. Metode yang digunakan adalah survei, yaitu mengumpulkan data dari anggota populasi guna menentukan status populasi pada waktu dilakukan penelitian. Instrumen yang digunakan untuk mengambil data adalah angket.

Populasi penelitian ini adalah mahasiswa Fakultas Ilmu Keolahragaan Universitas Negeri Yogyakarta. Teknik penentuan sampel menggunakan incidental sampling berjumlah 463 mahasiswa. Dalam penelitian ini, instrumen yang digunakan untuk mengumpulkan data adalah dengan menggunakan angket. Uji coba instrumen menggunakan sistem one shoot artinya data yang didapatkan semua diujikan. Selanjutnya data yang gugur tidak dimasukkan dalam penghitungan analisis data. Untuk menguji validitas instrumen pada penelitian ini pengolahan datanya menggunakan bantuan komputer dengan program SPSS seri 20. Untuk menguji reliabilitas instrumen pada penelitian ini pengolahan datanya 
menggunakan bantuan komputer dengan program SPSS seri 20. Hasil uji reliabilitas adalah 0,897 dengan hasil perhitungan $>\alpha(0.005)$

Analisis data menggunakan teknik analisis deskriptif kuantitatif yang dituangkan dalam bentuk persentase. Adapun teknik perhitungan untuk masing-masing butir untuk mencari besarnya frekuensi relatif (persentase) menurut Anas Sudijono 1995: 40) dengan rumus sebagai berikut:

$$
P=\frac{F}{N} x 100 \%
$$

Keterangan:

$\mathrm{P}=$ Angka Presentase

$\mathrm{F}=$ Frekuensi

$\mathrm{N}=$ Jumlah Subjek

\section{HASIL PENELITIAN DAN PEMBAHASAN}

Kesadaran mahasiswa Fakultas Ilmu Keolahragaan terhadap kesehatan lingkungan kampus dihasilkan skor minimal 145 dan skor maksimal 262, dan rerata 212,82. Setelah dilakukan pengategorian diketahui bahwa Kesadaran mahasiswa Fakultas Ilmu keolahragaan terhadap kesehatan lingkungan kampus adalah sebanyak 69 mahasiswa (14,9 \%) dengan kategori sangat baik, 357 mahasiswa (77,1 \%) dengan kategori baik, dan 36 mahasiswa $(7,8 \%)$ dengan kategori sedang, 1 mahasiswa $(0,2 \%)$ dengan kategori kurang, dan 0 mahasiswa (0,00 \%) dengan kategori sangat kurang. Distribusi frekuensi berdasarkan pengkategorian dapat dilihat berikut ini.

Tabel 2. Kesadaran Mahasiswa Fakultas Ilmu keolahragaan terhadap Kesehatan Lingkungan Kampus

\begin{tabular}{|c|c|c|c|c|}
\hline \multirow{2}{*}{ No. } & \multirow{2}{*}{ Kategori } & \multirow{2}{*}{ Interval } & \multicolumn{2}{|c|}{ Frekuensi } \\
\hline & & & Absolut & Persentase \\
\hline 1. & Sangat Baik & $222,6-265$ & 69 & $14,9 \%$ \\
\hline 2. & Baik & $180,1-222,5$ & 357 & $77,1 \%$ \\
\hline 3. & Sedang & $137,6-180,0$ & 36 & $7,8 \%$ \\
\hline 4. & Kurang & $95,1-137,5$ & 1 & $0,2 \%$ \\
\hline 5. & Sangat Kurang & $52,6-95,0$ & 0 & $0 \%$ \\
\hline \multicolumn{3}{|c|}{ Jumlah } & 463 & $100 \%$ \\
\hline
\end{tabular}

Kesadaran Mahasiswa Fakultas Ilmu Keolahragaan Universitas Negeri Yogyakarta terhadap Kesehatan Lingkungan Kampus (Erwin Setyo Kriswanto) 
Faktor-faktor yang mendeskripsikan kesadaran mahasiswa Fakultas Ilmu Keolahragaan terhadap kesehatan lingkungan kampus terdiri atas empat faktor, yaitu: (1) kesadaran penyediaan air minum, (2) kesadaran pengolahan sampah/limbah. (3) kesadaran pengelolaan polusi tanah, air dan udara, dan (4) kesadaran pengelolaan lingkungan. Secara rinci hasil penelitian tiap faktor adalah sebagai berikut:

1. Faktor kesadaran Penyediaan Air Minum

Kesadaran mahasiswa Fakultas Ilmu Keolahragaan terhadap kesehatan lingkungan kampus dilihat dari faktor kesadaran penyediaan air minum dihasilkan skor minimal 25 dan skor maksimal 63, dan rerata 49,94. Data yang terkumpul kemudian disesuaikan dengan kategori yang telah disusun. Jika skor maksimal yang dapat diperoleh adalah 65 sedangkan skor minimal 13 jumlah interval 5, dapat disusun kriteria sebagai berikut:

$$
\mathrm{i}=\underline{65-13}=10,4
$$

5

Tabel 3. Penentuan Kriteria untuk faktor kesadaran penyediaan air minum

\begin{tabular}{|c|c|}
\hline Interval & Kriteria \\
\hline $54,6-65,0$ & Sangat Baik \\
\hline $44,1-54,5$ & Baik \\
\hline $33,6-44,0$ & Sedang \\
\hline $23,1-33,5$ & Kurang \\
\hline $12,6-23,0$ & Sangat kurang \\
\hline
\end{tabular}

Setelah dilakukan pengategorian diketahui bahwa kesadaran mahasiswa Fakultas Ilmu Keolahragaan terhadap kesehatan lingkungan kampus dilihat dari faktor kesadaran penyediaan air minum adalah sebanyak 70 mahasiswa $(15,1 \%)$ dengan kategori sangat baik, 345 mahasiswa (74,5 \%) dengan kategori baik, 46 mahasiswa (9,9\%) dengan kategori sedang, 2 mahasiswa (0,4 \%) dengan kategori kurang, dan 0 mahasiswa $(0,00 \%)$ dengan kategori sangat kurang. Distribusi frekuensi berdasarkan pengategorian dapat dilihat pada tabel berikut ini. 
Tabel 4. Kesadaran Mahasiswa Fakultas Ilmu Keolahragaan terhadap Kesehatan Lingkungan Kampus berdasarkan Faktor Kesadaran Penyediaan Air Minum

\begin{tabular}{|c|c|c|c|c|}
\hline \multirow{2}{*}{ No. } & \multirow{2}{*}{ Kategori } & \multirow{2}{*}{ Interval } & \multicolumn{2}{|c|}{ Frekuensi } \\
\cline { 3 - 5 } & & & Absolut & Persentase \\
\hline 1. & Sangat Baik & $54,6-65,0$ & 70 & $15,1 \%$ \\
\hline 2. & Baik & $44,1-54,5$ & 345 & $74,5 \%$ \\
\hline 3. & Sedang & $33,6-44,0$ & 46 & $9,9 \%$ \\
\hline 4. & Kurang & $23,1-33,5$ & 2 & $0,4 \%$ \\
\hline 5. & Sangat Kurang & $12,6-23,0$ & 0 & $0 \%$ \\
\hline \multicolumn{2}{|c|}{ Jumlah } & 463 & $100 \%$ \\
\hline
\end{tabular}

2. Faktor Kesadaran Pengolahan Sampah/Limbah

Kesadaran mahasiswa Fakultas Ilmu Keolahragaan terhadap kesehatan lingkungan kampus dilihat dari faktor kesadaran pengolahan sampah/limbah dihasilkan skor minimal 45 dan skor maksimal 85, dan rerata 67,83. Data yang terkumpul kemudian disesuaikan dengan kategori yang telah disusun. Jika skor maksimal yang dapat diperoleh adalah 85 sedangkan skor minimal 17 jumlah interval 5, dapat disusun kriteria sebagai berikut:

$$
\mathrm{i}=\frac{85-17}{5}=13,6
$$

Tabel 5. Penentuan Kriteria untuk Faktor Kesadaran Pengolahan Sampah/Limbah

\begin{tabular}{|c|c|}
\hline Interval & Kriteria \\
\hline $71,5-85,0$ & Sangat Baik \\
\hline $57,9-71,4$ & Baik \\
\hline $44,3-57,8$ & Sedang \\
\hline $30,7-44.2$ & Kurang \\
\hline $17.0-30,6$ & Sangat Kurang \\
\hline
\end{tabular}

Kesadaran Mahasiswa Fakultas Ilmu Keolahragaan Universitas Negeri Yogyakarta terhadap Kesehatan Lingkungan Kampus (Erwin Setyo Kriswanto) 
Setelah dilakukan pengategorian diketahui bahwa Kesadaran mahasiswa Fakultas Ilmu Keolahragaan terhadap kesehatan lingkungan kampus dilihat dari faktor kesadaran pengolahan sampah/limbah adalah sebanyak 137 mahasiswa (29,6 \%) dengan kategori sangat baik, 297 mahasiswa (64,1 \%) dengan kategori baik, 29 mahasiswa (6,3 \%) dengan kategori sedang, 0 mahasiswa $(0,0 \%)$ dengan kategori kurang, dan 0 mahasiswa $(0,00 \%)$ dengan kategori sangat kurang. Distribusi frekuensi berdasarkan pengategorian dapat dilihat pada tabel berikut ini.

Tabel 6. Kesadaran mahasiswa Fakultas Ilmu Keolahragaan terhadap Kesehatan Lingkungan Kampus berdasarkan Faktor Kesadaran Pengolahan Sampah/Limbah

\begin{tabular}{|c|c|c|c|c|}
\hline \multirow{2}{*}{ No. } & \multirow{2}{*}{ Kategori } & \multirow{2}{*}{ Interval } & \multicolumn{2}{|c|}{ Frekuensi } \\
\cline { 3 - 5 } & & & Absolut & Persentase \\
\hline 1. & Sangat Baik & $71,5-85,0$ & 137 & $29,6 \%$ \\
\hline 2. & Baik & $57,9-71,4$ & 297 & $64,1 \%$ \\
\hline 3. & Sedang & $44,3-57,8$ & 29 & $6,3 \%$ \\
\hline 4. & Kurang & $30,7-44.2$ & 0 & $0 \%$ \\
\hline 5. & Sangat Kurang & $17.0-30,6$ & 0 & $0 \%$ \\
\hline \multicolumn{3}{|c|}{ Jumlah } & 463 & $100 \%$ \\
\hline
\end{tabular}

3. Faktor Kesadaran Pengelolaan Polusi Tanah, Air dan Udara

Kesadaran mahasiswa Fakultas Ilmu Keolahragaan terhadap kesehatan lingkungan kampus dilihat dari faktor kesadaran pengelolaan polusi tanah, air, dan udara dihasilkan skor minimal 24 dan skor maksimal 65, dan rerata 46,69. Data yang terkumpul kemudian disesuaikan dengan kategori yang telah disusun. Jika skor maksimal yang dapat diperoleh adalah 65 sedangkan skor minimal 13 jumlah interval 5, dapat disusun kriteria sebagai berikut:

$$
\mathrm{i}=\underline{65-13}=10,4
$$


Tabel 7. Penentuan Kriteria untuk Faktor Kesadaran Pengelolaan Polusi Tanah, Air dan Udara

\begin{tabular}{|c|c|}
\hline Interval & Kriteria \\
\hline $54,6-65,0$ & Sangat Baik \\
\hline $44,1-54,5$ & Baik \\
\hline $33,6-44,0$ & Sedang \\
\hline $23,1-33,5$ & Kurang \\
\hline $12,6-23,0$ & Sangat kurang \\
\hline
\end{tabular}

Setelah dilakukan pengkategorian diketahui bahwa Kesadaran mahasiswa Fakultas Ilmu Keolahragaan terhadap kesehatan lingkungan kampus dilihat dari faktor kesadaran pengelolaan polusi tanah, air dan udara adalah sebanyak 34 mahasiswa (7,3 \%) dengan kategori sangat baik, 270 mahasiswa (58,3 \%) dengan kategori baik, 149 mahasiswa (32,2 $\%)$ dengan kategori sedang, 10 mahasiswa (2,2 \%) dengan kategori kurang, dan 0 mahasiswa $(0,00 \%)$ dengan kategori sangat kurang. Distribusi frekuensi berdasarkan pengategorian dapat dilihat pada tabel berikut ini.

Tabel 8. Kesadaran mahasiswa Fakultas Ilmu Keolahragaan terhadap Kesehatan Lingkungan Kampus berdasarkan Faktor Kesadaran Pengelolaan Polusi Tanah, Air dan Udara

\begin{tabular}{|c|c|c|c|c|}
\hline \multirow{2}{*}{ No } & \multirow{2}{*}{ Kategori } & \multirow{2}{*}{ Interval } & \multicolumn{2}{|c|}{ Frekuensi } \\
\cline { 3 - 5 } & & & Absolut & Persentase \\
\hline 1. & Sangat Baik & $54,6-65,0$ & 34 & $7,3 \%$ \\
\hline 2. & Baik & $44,1-54,5$ & 270 & $58,3 \%$ \\
\hline 3. & Sedang & $33,6-44,0$ & 149 & $32,2 \%$ \\
\hline 4. & Kurang & $23,1-33,5$ & 10 & $2,2 \%$ \\
\hline 5. & Sangat Kurang & $12,6-23,0$ & 0 & $0 \%$ \\
\hline & \multicolumn{2}{|c|}{ Jumlah } & 463 & $100 \%$ \\
\hline
\end{tabular}

Kesadaran Mahasiswa Fakultas Ilmu Keolahragaan Universitas Negeri Yogyakarta terhadap Kesehatan Lingkungan Kampus (Erwin Setyo Kriswanto) 
4. Faktor Kesadaran Pengelolaan Lingkungan.

Kesadaran mahasiswa Fakultas Ilmu Keolahragaan terhadap kesehatan lingkungan kampus dilihat dari faktor kesadaran pengelolaan lingkungan dihasilkan skor minimal 25 dan skor maksimal 50, dan rerata 39,47. Data yang terkumpul kemudian disesuaikan dengan kategori yang telah disusun. Jika skor maksimal yang dapat diperoleh adalah 50 sedangkan skor minimal 10 jumlah interval 5, dapat disusun kriteria sebagai berikut:

$$
\mathrm{i}=\frac{50-10}{5}=8
$$

Tabel 9. Penentuan Kriteria Faktor Kesadaran Pengelolaan Lingkungan

\begin{tabular}{|c|c|}
\hline Interval & Kriteria \\
\hline $42,0-50,0$ & Sangat Baik \\
\hline $33,9-41,9$ & Baik \\
\hline $25,8-33,8$ & Sedang \\
\hline $17,7-25,7$ & Kurang \\
\hline $9,6-17,6$ & Sangat kurang \\
\hline
\end{tabular}

Setelah dilakukan pengkategorian diketahui bahwa kesadaran mahasiswa Fakultas Ilmu Keolahragaan terhadap kesehatan lingkungan kampus dilihat dari faktor kesadaran pengelolaan lingkungan adalah sebanyak 138 mahasiswa (29,8\%) dengan kategori sangat baik, 276 mahasiswa (59,6 \%) dengan kategori baik, 48 mahasiswa (10,4 \%) dengan kategori sedang, 1 mahasiswa $(0,2 \%)$ dengan kategori kurang, dan 0 mahasiswa $(0,00 \%)$ dengan kategori sangat kurang. Distribusi frekuensi berdasarkan pengategorian dapat dilihat pada tabel berikut ini.

Tabel 10. Kesadaran Mahasiswa Fakultas Ilmu Keolahragaan terhadap Kesehatan Lingkungan Kampus berdasarkan Faktor Kesadaran Pengelolaan Lingkungan

\begin{tabular}{|c|c|c|c|c|}
\hline \multirow{2}{*}{ No } & \multirow{2}{*}{ Kategori } & \multirow{2}{*}{ Interval } & \multicolumn{2}{|c|}{ Frekuensi } \\
\cline { 4 - 5 } & & Absolut & Persentase \\
\hline 1. & Sangat Baik & $42,0-50,0$ & 138 & $29,8 \%$ \\
\hline 2. & Baik & $33,9-41,9$ & 276 & $59,6 \%$ \\
\hline 3. & Sedang & $25,8-33,8$ & 48 & $10.4 \%$ \\
\hline 4. & Kurang & $17,7-25,7$ & 1 & $0,2 \%$ \\
\hline 5. & Sangat Kurang & $9,6-17,6$ & 0 & $0 \%$ \\
\hline \multicolumn{2}{|r}{ Jumlah } & 463 & $100 \%$ \\
\hline
\end{tabular}




\section{PEMBAHASAN}

Berdasarkan hasil penelitian kesadaran mahasiswa Fakultas Ilmu Keolahragaan terhadap kesehatan lingkungan kampus diketahui mayoritas dalam kategori baik, hal ini berbeda dari pengamatan awal bahwa mahasiswa masih ada yang merokok, membuang sampah tidak pada tempatnya atau kondisi kamar mandi atau toilet yang aromanya terasa kurang nyaman. Melihat kenyataan hasil penelitian ternyata hanya sedikit sekali mahasiswa yang belum memiliki kesadaran terhadap kesehatan lingkungan kampus. Dari yang sedikit ini juga memiliki andil terhadap kurang nyamannya kesehatan lingkungan kampus.

Kesadaran mahasiswa terhadap kesehatan lingkungan kampus khususnya terhadap faktor penyediaan air minum termasuk dalam kategori baik hal ini dikarenakan para mahasiswa sudah sadar terhadap bagaimana agar air dapat dimanfaatkan seoptimal mungkin untuk kehidupan termasuk menjaganya baik sumber mata airnya mupun cara pengolahannya. Hal lain yang masih belum optimal dilakukan adalah apabila ada kran yang mengalir terbuang mahasiswa belum tanggap untuk mematikannya, masih ada mahasiswa yang membuang sampah pada aliran air yang bisa jadi air tersebut dapat digunakan untuk kebutuhan hidup.

Kesadaran mahasiswa terhadap kesehatan lingkungan kampus khususnya terhadap faktor pengolahan sampah/limbah adalah baik. Hal ini tidak terlepas dari program pemerintah untuk menggunakan kembali barang yang tidak terpakai, mahasiswa juga menghemat pembelian barang baru bila barang yang rusak masih apabisa diperbaiki. Kesadaran yang belum optimal adalah penggunakan kertas yang berlebihan atau belum memanfaatkan kertas bekas untuk tugas atau juga tugas tidak dikirim via email.

Kesadaran mahasiswa terhadap kesehatan lingkungan kampus khususnya terhadap faktor kesadaran pengelolaan polusi tanah, air dan udara adalah cukup. Kesadaran dalam faktor ini belum optimal dikarenakan mahasiswa belum membuang sampah sesuai dengan jenis sampahnya. Di lingkungan kampus masih ada mahasiswa yang belum memarkir kendaraannya di tempat yang sesuai, masih dijumpainya mahasiswa yang merokok, masih ada mahasiswa yang mengendarai kendaraan bermotor yang suaranya tidak terkontrol.

Kesadaran mahasiswa terhadap kesehatan lingkungan kampus khususnya terhadap faktor pengelolaan lingkungan adalah baik. Keadaan ini dapat diakibatkan kesadaran 
mahaiswa yang peduli terhadap keindahan linkungan dengan tidak memotong atau merusak tanaman di sekitar kampus. Mahsiswa juga aktif mengampanyekan tentang pentingnya pengelolaan lingkungan, respons mahasiswa juga tinggi apabila ada yang membuang sampah tidak pada tempatnya.

Kesadaran mahasiswa yang baik terhadap kesehatan lingkungan kampus didasari beberapa hal antara lain, kebiasaan berperilaku hidup sehat yang sudah diajarkan orang tua di rumahnya, faktor pendidikan atau pengetahuan mahasiswa terhadap lingkungan dan faktor gender. Pada faktor gender ini kecenderungan wanita lebih sadar dibanding dengan laki-laki hal ini sejalan dengan pernyataan Murat Cancurt (2008: 10) gender adalah faktor yang signifikan yang memengaruhi kesadaran untuk pencemaran lingkungan, wanita lebih sadar daripada laki-laki. Kalangan terdidik ditemukan lebih sadar daripada yang kurang berpendidikan.

Faktor yang lain yang dapat mendukung adalah adanya aturan untuk menjaga lingkungan baik itu larangan membuang sampah, larangan merokok, atau kesadaran dalam menggunakan sepeda di lingkungan kampus. Kesadaran timbul sebagai akibat dari interaksi antara tindakan manusia dan faktor lingkungan di luar kontrol manusia yang langsung didapat melalui kegiatan manusia (Beatrice M.O, 2011: 62). 


\section{KESIMPULAN}

Berdasarkan hasil penelitian dapat disimpulkan bahwa Kesadaran mahasiswa Fakultas Ilmu Keolahragaan terhadap kesehatan lingkungan kampus adalah sebanyak 129 mahasiswa $(27,92 \%)$ dengan kategori sangat baik, 309 mahasiswa $(66,88 \%)$ dengan kategori baik, dan 24 mahasiswa $(5,20 \%)$ dengan kategori sedang, 0 mahasiswa $(0,00 \%)$ dengan kategori kurang, dan 0 mahasiswa $(0,00 \%)$ dengan kategori sangat kurang.

Agar kesadaran mahasiswa terhadap kesehatan lingkungan kampus dapat meningkat tentu diperlukan integrasi konsep kurikulum mengenai lingkungan. Program pendidikan lingkungan integratif yang demikian penting karena dapat memberikan pengetahuan yang diinginkan, keterampilan, nilai dan sikap. Pada gilirannya akan memperluas pemahaman konsep yang relevan bagi mahasiswa yang memungkinkan mahasiswa secara kritis menilai konsekuensi dari tindakannya ketika melakukan berbagai tindakan terkait kesehatan lingkungan. Kampus sebaiknya menunjukkan komitmen nyata terhadap prinsip dan praktek kesehatan lingkungan. Kampus dapat membuat program terkait praktek lingkungan seperti pembersihan (kerja bakti), hari penanaman pohon atau lainnya yang melibatkan mahasiswa. Hal ini akan memberdayakan mahasiswa dengan pengetahuan lingkungan sehingga dapat aktif memainkan peran dalam aksi lingkungan dan menanamkan budaya yang akan membuat kampus mencapai tujuannya dalam mewujudkan lingkungan yang sehat. 


\section{DAFTAR PUSTAKA}

Arif Sumantri. (2010). Kesehatan Lingkungan dan Perspektif Islam. Jakarta: Kencana Prenada Media Group

A.W Wijaya. (1984). Kesadaran Hukum Manusia dan Masyarakat Pancasila. Jakarta: Era Swasta.

Beatrice M,O. William, W. Samuel S. (2011). An Evaluation of University Students' Awarreness of Environmental Helth Risk and Their Attitudes Towards The Risk. African Journal of Education and Technology, Volume 1 Number 3.

Budiman Chandra. (2006). Pengantar Kesehatan Lingkungan. Jakarta: EGC.

Depkes R.I. (2009). Undang-undang Republik Indonesia No. 36. Tahun 2009 Tentang Kesehatan.

Erwin Setyo Kriswanto, (2012). Konsep, Proses, dan Aplikasi dalam Pendidikan Kesehatan. Yogyakarta: Fakultas Ilmu Keolahragaan.

Juli Soemirat. (2011). Kesehatan Lingkungan. Yogyakarta: Gadjah Mada University Press.

Murat Cankurt. (2008). Awareness to Environmental Polution in Turkey. Departement of Agricultural Economics, Ege University.

Soekidjo Notoatmodjo. (2003). Ilmu Kesehatan Masyarakat. Jakarta: Rineka Cipta. . (2003). Pendidikan dan Perilaku Kesehatan. Jakarta: RhinekaCipta.

Suharsimi Arikunto. (2006). Prosedur Penelitian, Suatu Pendekatan Praktik. Jakarta: PT. Rineka Cipta.

Word Bank. (1985). Information and Training For Low-cost Water Supply and Sanitatio. Modul No. 3.2a The Team Effort. Washington DC: Word Bank. 